九州大学学術情報リポジトリ

Kyushu University Institutional Repository

\title{
Genetic Diversity of Colored Rice Lines Based on Botanical Characteristics and Simple Sequence Repeat (SSR) Markers
}

$\mathrm{Ji}$, Hee Chung

National Livestock Research Institute, Rural Development Administration

Kim, Young Il

Collage of Agriculture and Life Science, Chungnam National university

Lee, Hee Bong

Collage of Agriculture and Life Science, Chungnam National university

Cho, Jin-Woong

Collage of Agriculture and Life Science, Chungnam National university

他

https://doi.org/10.5109/9316

出版情報 : 九州大学大学院農学研究院紀要. 52 (2)，pp. 287-293，2007-10-29. Faculty of Agriculture, Kyushu University

バージョン:

権利関係 : 


\title{
Genetic Diversity of Colored Rice Lines Based on Botanical Characteristics and Simple Sequence Repeat (SSR) Markers
}

\author{
Hee Chung $\mathrm{JI}^{1}$, Young Il KIM${ }^{2}$, Hee Bong $\mathrm{LEE}^{2}$, Jin-Woong $\mathrm{CHO}^{2}$, \\ Sung SEO ${ }^{1}$ and Takeo YAMAKAWA*
}

\author{
Laboratory of Plant Nutrition, Division of Soil Science and Plant Production, \\ Department of Plant Resources, Faculty of Agriculture, Kyushu University, \\ 6-10-1 Hakozaki, Fukuoka 812-8581, Japan \\ (Received May 28, 2007 and accepted July 17, 2007)
}

\begin{abstract}
This study aimed to evaluate a genetic diversity by simple sequence repeat (SSR) markers and morphological characteristics among colored rice lines of the developed CNU (Chungnam National University) lines. Development of colored rice cultivars is one of the main breeding goals to meet a consumer's needs in Korea. Total 34 colored rice lines that selected from advanced population improved by crosses and artificial mutation techniques were tested. SSR analysis of colored rice lines showed 20 polymorphic bands using seven SSR primer pairs (RM pairs) and had average three alleles per SSR marker. The average of genetic distance based on SSR marker was 0.56 and ranged from 0.22 to 0.81 . The genetic distance was higher in each different pedigree or cross combinations than that in the same pedigree. The mean of polymorphism information content (PIC) were 0.48 and the ranges of PIC reached 0.08 (RM 579 ) to 0.67 (RM 457), respectively. Genetic classification of 34 colored rice lines by SSR marker analysis were divided into four groups when genetic distance was more than 0.5. The results of cluster analysis of 34 colored rice lines by SSR markers were compared with the results of cluster analysis using morphological characteristics, i.e. color of spikelet and seed coat, and awn existence and its length.
\end{abstract}

\section{INTRODUCTION}

Genetic diversity is an essential element for the development of new line of rice, and has an importance for hybrid combinations in colored rice. It is also useful for genetic improvement and for the development of colored rice for desired traits such as yield, quality, pest and insect resistance, and stress tolerance.

Maintaining genetic diversity and improving the management of genetic resources are important issues among colored rice breeders. Many methodologies exist for the assessment of genetic diversity in colored rice. Since the morphological characteristics are influenced by the environment, they sometimes do not express genetic diversity. In addition the evaluation based on such traits is time and expenses consuming (Dubreuil et al., 1996). Nevertheless morphological data are still widely used for selection of genetically diverse parents from a colored rice collection. But the morphological differences are usually determined by a small number of genes and may not be representative of genetic divergence in the entire genome (Singh et al., 1999; Brown-Guedira et al., 2000). Compared with morphological variation, molecular polymorphism is generally considered to be independence of the environment (Gauthier et al., 2002). Molecular genetic techniques can be applied for the evaluation of genetic diversity and

${ }^{1}$ Grassland \& Forages Division, National Livestock Research Institute, Rural Development Administration, Cheonan, 330-800, South Korea

${ }^{2}$ Department of Crop Science, Collage of Agriculture and Life Science, Chungnam National University, Daejeon, 305-764, South Korea

* Corresponding author (E-mail: yamakawa@agr.kyushu-u. ac.jp) to traditional approaches in the conservation and utilization of plant genetic resources (Gauthier et al., 2002; Ghebru et al., 2002).

DNA based markers provide some useful information on genetic diversity. The information provided by molecular markers can be used in breeding programs to better estimate the genetic value to selection (Hospital et al., 1997) Molecular markers allow for the selection of desired traits based on genotype rather than phenotype and can therefore complement and accelerate plant breeding programs. They can also be used for the early selection of traits such as persistence, competitive ability and seed yield, which are not expressed during the juvenile phase. Molecular markers have been successfully used for the construction of genetic linkage maps and for the identification and tagging of economically important genes and quantitative trait loci (QTLs) in a large number of plant species (Rafalski et al., 1996; Staub et al., 1996; Mohan et al., 1997; Kumar, 1999).

Molecular markers can provide an effective tool for efficient selection of desired agronomic traits since they are based on the plant genotypes and thus are independent of environmental variation. Highly informative molecular markers, such as simple sequence repeats (SSRs), can greatly accelerate breeding programs. SSRs are very abundant and dispersed throughout the genome, usually co-dominant inheritance, and can uncover a great number of polymorphisms since multi-allelic loci are very common (Chin et al., 1996). The use of molecular markers can facilitate rice breeding by means of marker-assisted selection (MAS) to improve agronomical important traits such as yield, quality and disease resistance. This study aims to evaluate genetic diversity by simple sequence repeat (SSR) markers among colored rice lines of the developed CNU lines. 


\section{MATERIALS AND METHODS}

\section{Plant materials and DNA isolation}

CNU lines were planted in randomized complete block design (RCBD) on April 30, 2004 at Chungnam National University's Farm (Table 1). CNU lines were planted in a single row with $0.15 \mathrm{~m}$ spacing between plants and $0.3 \mathrm{~m}$ spacing between rows. Genomic DNA of the $34 \mathrm{CNU}$ lines was isolated from young leaves following the method described by Yu and Pauls (1994). For each sample, four fresh leaf disks (100 mg) were put into $400 \mu \mathrm{L}$ of DNA extraction buffer in a $1.5 \mathrm{~mL}$ of Eppendorf tube and homogenized with a plastic pestle (Mandel Scientific Company Ltd.). Then $400 \mu \mathrm{L}$ of 24:1 chloroform/isoamyl alcohol was added to the homogenized solution, vortexed and left at room temperature for $30 \mathrm{~min}$. The homogenate was spun in the tube at $10,500 \mathrm{rpm}$ for $2 \mathrm{~min}$ and $350 \mu \mathrm{L}$ of supernatant were transferred in to a new $1.5 \mathrm{~mL}$ of Eppendorf tube. For DNA precipitation, an equal volume $(350 \mu \mathrm{L})$ of isopropanol was added to the tube, left at room temperature for $5 \mathrm{~min}$ and then spun at 11,000 rpm for $5 \mathrm{~min}$.
Then, the DNA pellet was air-dried at room temperature for 30 to $60 \mathrm{~min}$ before it was dissolved in $200 \mu \mathrm{L}$ of DNase-free $\mathrm{dH}_{2} \mathrm{O}$ at $4{ }^{\circ} \mathrm{C}$ overnight. The supernatant was collected after centrifugation at 1,300 rpm for $2 \mathrm{~min}$, yielded about $25 \mathrm{ng} \mu \mathrm{L}^{-1}$ of DNA.

\section{PCR amplification and product electrophoresis}

PCR amplifications were performed in $25 \mu \mathrm{L}$ of reaction mixture containing $5 \mu \mathrm{L}$ of genomic DNA ( $5 \mathrm{ng}$ ), $1 \mu \mathrm{L}$ of dNDP $(2.5 \mathrm{mM}), 2.5 \mu \mathrm{L}$ of $10 \times$ buffer, $0.5 \mu \mathrm{L}$ of Tag polymerse of $5 \mathrm{U} \mu \mathrm{L}^{-1}$ (TaKaRa), $0.5 \mu \mathrm{L}$ of $\mathrm{P}$-primer (50 ng $\mu \mathrm{L}^{-1}$ ), $0.5 \mu \mathrm{L}$ of $\mathrm{M}$-primer (50 ng $\mu \mathrm{L}^{-1}$ ) using SSR primer pair shown in Table $2,15 \mu \mathrm{L}$ of $\mathrm{dH}_{2} \mathrm{O}$. The PCR amplification conditions were programmed as one cycles of denaturation at $72^{\circ} \mathrm{C}$ for 5 min followed by 35 cycles amplification with 3 min denaturing at $95^{\circ} \mathrm{C}, 1 \mathrm{~min}$ at $95^{\circ} \mathrm{C}, 1 \mathrm{~min}$ at $55^{\circ} \mathrm{C}, 2 \mathrm{~min}$ at $72^{\circ} \mathrm{C}$. PCR reaction was performed using the GeneAmp ${ }^{\circledR}$ PCR System 2700 (ABI, U.S.A).

\section{Genetic analysis}

All 34 lines were used to screen the SSR primers

Table 1. Lines and their cross combination of the 34 colored rice used in the study

\begin{tabular}{|c|c|c|c|}
\hline Lines & Primer & Lines & Primer \\
\hline Check & Heukjinjubyeo & CNU72 & Jekminamgeoma× Ou349, $\mathrm{F}_{7}$ \\
\hline CNU01 & Dohoku149, $\mathrm{M}_{6}$ & CNU73 & Jekminamgeoma $\times$ Ou $349, \mathrm{~F}_{7}$ \\
\hline CNU02 & Dohoku149, $\mathrm{M}_{6}$ & CNU74 & Jekminamgeomax Ou349, $\mathrm{F}_{7}$ \\
\hline CNU30 & Dohoku149, $\mathrm{M}_{6}$ & CNU76 & Jekminamgeoma $\times$ Ou349, $\mathrm{F}_{7}$ \\
\hline CNU33 & Suwon451× Milyang $152, \mathrm{~F}_{7}$ & CNU77 & Ou349× Suwon451, $\mathrm{F}_{7}$ \\
\hline CNU39 & Suwon451× Milyang $152, \mathrm{~F}_{7}$ & CNU80 & Suwon425× Killimheukmi, $\mathrm{F}_{7}$ \\
\hline CNU40 & Heuknambyeo× Heukjinjubyeo, $\mathrm{F}_{7}$ & CNU81 & Suwon425× Killimheukmi, $\mathrm{F}_{7}$ \\
\hline CNU41 & Heuknambyeo× Heukjinjubyeo, $\mathrm{F}_{7}$ & CNU83 & Suwon425× Killimheukmi, $\mathrm{F}_{7}$ \\
\hline CNU43 & Heuknambyeo× Heukjinjubyeo, $\mathrm{F}_{7}$ & CNU85 & Suwon425× Killimheukmi, $\mathrm{F}_{7}$ \\
\hline CNU44 & Heuknambyeo× Heukjinjubyeo, $\mathrm{F}_{7}$ & CNU86 & Suwon425× Killimheukmi, $\mathrm{F}_{7}$ \\
\hline CNU45 & Heuknambyeo× Heukjinjubyeo, $\mathrm{F}_{7}$ & CNU87 & Suwon425× Killimheukmi, $\mathrm{F}_{7}$ \\
\hline CNU46 & Heuknambyeo× Heukjinjubyeo, $\mathrm{F}_{7}$ & CNU88 & Suwon425× Killimheukmi, $\mathrm{F}_{7}$ \\
\hline CNU48 & Heuknambyeo× Heukjinjubyeo, $\mathrm{F}_{7}$ & CNU90 & Suwon425× Killimheukmi, $\mathrm{F}_{7}$ \\
\hline CNU50 & Heuknambyeo× Heukjinjubyeo, $\mathrm{F}_{7}$ & CNU91 & Suwon425× Killimheukmi, $\mathrm{F}_{7}$ \\
\hline CNU52 & Heuknambyeo $\times$ Heukjinjubyeo, $\mathrm{F}_{7}$ & CNU93 & Suwon425× Killimheukmi, $\mathrm{F}_{7}$ \\
\hline \multirow{2}{*}{$\begin{array}{l}\text { CNU54 } \\
\text { CNU71 }\end{array}$} & \multirow{2}{*}{$\begin{array}{l}\text { Heuknambyeo× Heukjinjubyeo, } \mathrm{F}_{7} \\
\text { Jekminamgeoma× Ou349, } \mathrm{F}_{7}\end{array}$} & CNU94 & Suwon425× Killimheukmi, $\mathrm{F}_{7}$ \\
\hline & & Total & 34 Lines \\
\hline
\end{tabular}

Table 2. SSR primer pairs, their sequences and repeat sequence used in this study

\begin{tabular}{|c|c|c|}
\hline Primer pair & Sequence & Repeat sequence \\
\hline RM 503 & $\begin{array}{l}\text { CACCTTTCACACACACACAC// } \\
\text { GCCCCACTAACAAAACCAAG }\end{array}$ & (CA) $59,(\mathrm{TA}) 26$ \\
\hline RM 504 & $\begin{array}{l}\text { TCTATAATGTAGCCCCCCCC// } \\
\text { TTTCAGGGGCTTCTACCAAC }\end{array}$ & $(\mathrm{CA}) 9$ \\
\hline RM 528 & $\begin{array}{l}\text { GGCATCCAATTTTACCCCTC// } \\
\text { AAATGGAGCATGGAGGTCAC }\end{array}$ & $(\mathrm{AGAT}) 9$ \\
\hline RM 577 & $\begin{array}{l}\text { GCTTTCCCTCTAACCCCTCT// } \\
\text { GGATGTACCGCTGACATGAA }\end{array}$ & $(\mathrm{TA}) 9,(\mathrm{CA}) 8$ \\
\hline RM 579 & $\begin{array}{l}\text { TCCGAGTGGTTATGCAAATG// } \\
\text { AATTGTGTCCAATGGGCTGT }\end{array}$ & (GA)25 \\
\hline RM 457 & $\begin{array}{l}\text { CTCCAGCATGGCCTTTCTAC// } \\
\text { ACCTGATGGTCAAAGATGGG }\end{array}$ & (TTAA)5 \\
\hline RM 553 & $\begin{array}{l}\text { AACTCCACATGATTCCACCC// } \\
\text { GAGAAGGTGGTTGCAGAAGC }\end{array}$ & (CT) 10 \\
\hline
\end{tabular}


(Table 2) for PCR amplification and polymorphism. The number of alleles were recorded and the polymorphism information content (PIC) of an SSR locus was calculated as described by Saal and Wricke (1999), based on expected heterozygosity (Hedrick, 1985):

$$
\mathrm{PIC}=1-\sum_{\mathrm{i}=1}^{\mathrm{k}} P_{i}
$$

Where $p_{i}$ is the frequency of the i-th allele out of the total number of alleles at an SSR locus, and $\mathrm{k}$ is the total number of different alleles for that locus. For phylogenetic analysis, only the data for the polymorphic SSR loci were entered for all DNA samples, and a " 1 " or " 0 " was used if an allele was present or absent for a genotype, respectively. The data were analyzed using the computer program TREECON (Van de Peer and De Wachter, 1994). The estimation of genetic distance was based on the method described by Nei and Li (1979).

All 34 lines were clustered by the estimated genetic distance, and phylogenetic tree topology was inferred with the clustering method of the Unweighted Pair Group Method Using Arithmetic Average (UPGMA).

\section{RESULTS AND DISCUSSION}

\section{Botanical characteristics of the developed colored rice}

The culm length of Heukjinjubyeo as check line was $73.8 \mathrm{~cm}$ while that of CNU33 and CNU76 was $93.8 \mathrm{~cm}$ and $90.6 \mathrm{~cm}$, respectively, but that of CNU87 was smaller rather than other varieties. Panicle length of check line was $22.3 \mathrm{~cm}$ while CNU33 and CNU83 was little longer than check line. The number of spikelet per panicle of check line was 149, that of CNU33 was the highest among $34 \mathrm{CNU}$ lines but that of CNU80 was the lowest as 92. The result of this experiment showed more wide range variation in the spikelet number per panicle. The numbers of effective branches and panicles per plant were more CNU73 and CNU77 than check line but those of CNU74 were smaller than other CNU lines. The check line was the earliest variety compared with other ones in days of heading (Table 3). The 1000 grain weight of the CNU90 and CNU76 was heavier than that of check line, but that of CNU54 was the lightest among 34 CNU lines (Table 4).

Table 3. Agronomic characteristics for the 34 colored rice lines

\begin{tabular}{|c|c|c|c|c|c|c|c|}
\hline Lines & $\begin{array}{c}\text { Culm } \\
\text { length } \\
(\mathrm{cm})\end{array}$ & $\begin{array}{c}\text { Panicle } \\
\text { length } \\
(\mathrm{cm})\end{array}$ & $\begin{array}{c}\text { Spikelets } \\
\text { per panicle }\end{array}$ & $\begin{array}{c}\text { Secondary } \\
\text { rachis branches }\end{array}$ & $\begin{array}{l}\text { Panicles } \\
\text { per plant }\end{array}$ & $\begin{array}{l}\text { Effective } \\
\text { branches }\end{array}$ & $\begin{array}{l}\text { Days to } \\
\text { heading }\end{array}$ \\
\hline Check & 73.8 & 22.3 & 149 & 11 & 9 & 9 & 91 \\
\hline CNU01 & 76.8 & 21.9 & 97 & 9 & 10 & 9 & 101 \\
\hline CNU02 & 79.1 & 24.6 & 119 & 9 & 11 & 10 & 99 \\
\hline CNU30 & 81.0 & 22.5 & 100 & 11 & 12 & 12 & 115 \\
\hline CNU33 & 93.8 & 25.1 & 169 & 15 & 9 & 9 & 117 \\
\hline CNU39 & 81.9 & 22.9 & 156 & 13 & 9 & 8 & 115 \\
\hline CNU40 & 71.3 & 19.2 & 153 & 12 & 11 & 11 & 117 \\
\hline CNU41 & 71.2 & 22.0 & 142 & 11 & 11 & 11 & 108 \\
\hline CNU43 & 66.9 & 20.0 & 139 & 11 & 12 & 11 & 113 \\
\hline CNU44 & 88.2 & 22.4 & 133 & 13 & 10 & 10 & 107 \\
\hline CNU45 & 71.9 & 20.7 & 138 & 12 & 12 & 12 & 107 \\
\hline CNU46 & 74.2 & 20.8 & 151 & 12 & 10 & 10 & 107 \\
\hline CNU48 & 79.4 & 22.0 & 143 & 12 & 12 & 11 & 112 \\
\hline CNU50 & 76.8 & 22.0 & 126 & 11 & 11 & 9 & 112 \\
\hline CNU52 & 73.8 & 20.7 & 141 & 13 & 10 & 10 & 112 \\
\hline CNU54 & 73.9 & 23.5 & 139 & 12 & 11 & 10 & 112 \\
\hline CNU71 & 66.1 & 22.1 & 165 & 12 & 11 & 11 & 111 \\
\hline CNU72 & 74.2 & 20.8 & 118 & 10 & 10 & 10 & 111 \\
\hline CNU73 & 74.3 & 25.3 & 155 & 13 & 14 & 14 & 111 \\
\hline CNU74 & 82.3 & 20.1 & 162 & 12 & 7 & 7 & 113 \\
\hline CNU76 & 90.6 & 22.2 & 96 & 9 & 9 & 9 & 115 \\
\hline CNU77 & 79.5 & 21.2 & 98 & 9 & 14 & 13 & 108 \\
\hline CNU80 & 79.2 & 22.5 & 92 & 9 & 9 & 8 & 110 \\
\hline CNU81 & 79.9 & 21.7 & 100 & 11 & 9 & 9 & 113 \\
\hline CNU83 & 83.3 & 25.1 & 138 & 13 & 11 & 11 & 113 \\
\hline CNU85 & 80.4 & 19.7 & 137 & 9 & 10 & 10 & 105 \\
\hline CNU86 & 66.1 & 19.3 & 95 & 7 & 8 & 8 & 105 \\
\hline CNU87 & 58.3 & 21.3 & 132 & 11 & 10 & 10 & 108 \\
\hline CNU88 & 81.9 & 21.0 & 103 & 8 & 12 & 12 & 105 \\
\hline CNU90 & 72.1 & 17.9 & 159 & 11 & 9 & 9 & 108 \\
\hline CNU91 & 67.5 & 22.4 & 148 & 10 & 11 & 10 & 108 \\
\hline CNU93 & 64.2 & 20.3 & 149 & 10 & 11 & 10 & 115 \\
\hline CNU94 & 80.8 & 20.0 & 146 & 10 & 9 & $\begin{array}{r}9 \\
---\end{array}$ & 115 \\
\hline Min. & 58.3 & 17.9 & 92 & 7 & 7 & 7 & 91 \\
\hline Max. & 93.8 & 25.3 & 169 & 15 & 14 & 14 & 117 \\
\hline Mean & 76.2 & 21.7 & 133 & 10 & 10 & 10 & 110 \\
\hline
\end{tabular}


Table 4. Yield characteristics in 34 colored rice lines

\begin{tabular}{|c|c|c|c|c|c|c|}
\hline \multirow[b]{2}{*}{ Lines } & \multirow{2}{*}{$\begin{array}{l}1000 \text { grain } \\
\text { weight (g) }\end{array}$} & \multirow{2}{*}{$\begin{array}{l}\text { Ripening } \\
\text { Ratio (\%) }\end{array}$} & \multicolumn{3}{|c|}{ Grain } & \multirow{2}{*}{$\begin{array}{c}\text { Yield } \\
\left.\text { (g plant }^{-1}\right)\end{array}$} \\
\hline & & & $\begin{array}{l}\text { Length } \\
\text { (A)(mm) }\end{array}$ & $\begin{array}{l}\text { Width } \\
\text { (B) (mm) }\end{array}$ & $\mathrm{A} / \mathrm{B}$ & \\
\hline Check & 22.6 & 91.4 & 5.6 & 2.8 & 2.0 & 28.7 \\
\hline CNU01 & 23.1 & 94.5 & 5.8 & 2.4 & 2.5 & 21.9 \\
\hline CNU02 & 24.8 & 92.3 & 6.4 & 2.7 & 2.4 & 29.1 \\
\hline CNU30 & 24.6 & 93.6 & 5.6 & 3.0 & 1.9 & 28.4 \\
\hline CNU33 & 23.3 & 89.7 & 5.7 & 2.7 & 2.1 & 31.8 \\
\hline CNU39 & 23.9 & 90.3 & 5.1 & 3.0 & 1.7 & 30.3 \\
\hline CNU40 & 21.0 & 90.1 & 5.5 & 2.6 & 2.1 & 31.8 \\
\hline CNU41 & 22.0 & 89.9 & 6.0 & 2.8 & 2.2 & 31.0 \\
\hline CNU43 & 19.2 & 92.3 & 5.9 & 2.6 & 2.2 & 29.6 \\
\hline CNU44 & 21.3 & 89.8 & 5.3 & 2.8 & 1.9 & 25.4 \\
\hline CNU45 & 24.3 & 91.3 & 5.6 & 2.9 & 1.9 & 30.6 \\
\hline CNU46 & 21.5 & 91.7 & 5.5 & 2.5 & 2.2 & 29.8 \\
\hline CNU48 & 22.9 & 92.3 & 5.7 & 2.9 & 2.0 & 36.3 \\
\hline CNU50 & 23.2 & 93.1 & 5.4 & 2.5 & 2.1 & 29.1 \\
\hline CNU52 & 19.0 & 92.3 & 5.5 & 2.5 & 2.2 & 25.6 \\
\hline CNU54 & 19.0 & 90.3 & 6.3 & 2.7 & 2.4 & 27.0 \\
\hline CNU71 & 23.2 & 90.8 & 5.8 & 2.8 & 2.1 & 38.2 \\
\hline CNU72 & 24.9 & 91.3 & 5.5 & 2.8 & 2.0 & 26.7 \\
\hline CNU73 & 22.6 & 89.9 & 5.6 & 2.9 & 1.9 & 37.8 \\
\hline CNU74 & 28.6 & 92.0 & 5.4 & 2.9 & 1.8 & 29.8 \\
\hline CNU76 & 26.9 & 94.3 & 5.8 & 3.0 & 1.9 & 23.4 \\
\hline CNU77 & 27.7 & 93.3 & 5.9 & 2.9 & 2.0 & 34.7 \\
\hline CNU80 & 25.8 & 91.3 & 6.1 & 3.0 & 2.1 & 20.2 \\
\hline CNU81 & 27.0 & 91.3 & 6.0 & 2.9 & 2.1 & 23.0 \\
\hline CNU83 & 25.2 & 93.5 & 5.9 & 3.1 & 1.9 & 36.9 \\
\hline CNU85 & 27.4 & 95.5 & 5.7 & 2.9 & 1.9 & 34.7 \\
\hline CNU86 & 26.0 & 93.3 & 5.6 & 2.9 & 2.0 & 18.4 \\
\hline CNU87 & 27.8 & 94.4 & 6.2 & 2.9 & 2.2 & 34.8 \\
\hline CNU88 & 27.6 & 92.3 & 5.6 & 3.0 & 1.9 & 30.6 \\
\hline CNU90 & 27.1 & 88.1 & 5.6 & 2.9 & 1.9 & 34.2 \\
\hline CNU91 & 25.6 & 90.3 & 6.6 & 2.9 & 2.3 & 36.5 \\
\hline CNU93 & 23.7 & 90.7 & 6.0 & 2.7 & 2.2 & 35.2 \\
\hline CNU94 & 26.2 & 91.7 & 5.9 & 2.8 & 2.1 & 31.5 \\
\hline Min. & 19.0 & 87.0 & 4.8 & 2.4 & 1.6 & 18.4 \\
\hline Max. & 27.1 & 95.7 & 6.6 & 3.1 & 2.5 & 38.2 \\
\hline Mean & 23.6 & 91.5 & 5.7 & 2.8 & 2.0 & 32.5 \\
\hline
\end{tabular}

Check line was similar to the mean values of $34 \mathrm{CNU}$ lines in the ripening ratio (\%) but CNU85 was little higher than check line, while CNU90 was lowest. Heukjinjubyeo yielded less than CNU71 and CNU73 due to be small in panicles per plant and 1000 grain weight (Moon et al., 1998). One thousand grain weight of CNU74 and CNU87 were $28.6 \mathrm{~g}$ and $27.8 \mathrm{~g}$, respectively. However that of CNU52 and CNU54 was lighter than other CNU lines.

Yield per plant in Heukjinju was $28.7 \mathrm{~g}$ while that of CNU71 and CNU73 was $38.2 \mathrm{~g}$ and $37.8 \mathrm{~g}$, respectively, because these varieties may be higher value in spikelets per panicles and effective branches.

In the ear characteristics, most of colored rice varieties showed easily shattering, while CNU33 was very hard to shattering. Seed shattering is still the major component of yield loss, because shattering before harvest in paddy fields. Understanding the inheritance of the shattering trait is necessary to decrease yield reduction, as the losses have been estimated 26\% (Schertz and Boedicker, 1977) to more than 40\% (Porter et al., 1994). Simple inheritance trait of one or two dominant gene(s) has been proposed to describe the inheritance of seed shattering (Woods and Clark, 1976; Elliot and Perlinger, 1977).

Awn of almost all these developed varieties was none or short character, while CNU33 and CNU73 have a long awn. The glume color of these developed colored rice lines was brown, black, gold and straw color. The testa color of $34 \mathrm{CNU}$ lines showed three kinds of purple, brown and white, and that of most CNU lines were purple (Table 5).

\section{Number of allelic bands and PIC values}

As an indication of polymorphism, the number of allelic band and their frequency at each locus was analyzed. All marker loci were polymorphic and resulted in total of 20 allelic bands among 34 colored rice lines. The number of allelic band per loci ranged from two to five, PIC values for SSR loci ranged from 0.08 (RM457) to 0.67 (RM579) and the average of PIC value is 0.48 (Table 6). 
Table 5. Grain characteristics in the 34 colored rice lines

\begin{tabular}{|c|c|c|c|c|}
\hline Lines & Shattering & Awn & Glume color & Testa color \\
\hline Check & Easy & Absent & B F & Purple \\
\hline CNU01 & Easy & Absent & Straw & Purple \\
\hline CNU02 & Easy & Absent & Straw & Purple \\
\hline CNU30 & Easy & Absent & B F & Purple \\
\hline CNU33 & Hard & $\mathrm{L} \& \mathrm{~F}$ & Straw & Purple \\
\hline CNU39 & Moderately & Absent & Brown & Brown \\
\hline CNU40 & Moderately & Absent & Black & L B \\
\hline CNU41 & Easy & Absent & Black & Purple \\
\hline CNU43 & Easy & Absent & B S & V P \\
\hline CNU44 & Easy & S \& P & Brown & V P \\
\hline CNU45 & Easy & Absent & B F & L B \\
\hline CNU46 & Moderately & Absent & Straw & V P \\
\hline CNU48 & Easy & Absent & Straw & Brown \\
\hline CNU50 & Moderately & S \& P & Brown & V P \\
\hline CNU52 & Easy & S \& P & Black & Brown \\
\hline CNU54 & Easy & Absent & Brown & V P \\
\hline CNU71 & Easy & S \& P & B F & Purple \\
\hline CNU72 & Easy & Absent & Straw & Purple \\
\hline CNU73 & Moderately & L \& F & B F & Purple \\
\hline CNU74 & Easy & Absent & B S & V P \\
\hline CNU76 & Moderately & S \& P & Straw & Purple \\
\hline CNU77 & Very easy & $S \& F$ & Gold & White \\
\hline CNU80 & Very easy & Absent & Straw & Purple \\
\hline CNU81 & Easy & Absent & Brown & V P \\
\hline CNU83 & Moderately & Absent & Black & Brown \\
\hline CNU85 & Easy & S \& P & $\mathrm{B} \mathrm{F}$ & Brown \\
\hline CNU86 & Very easy & Absent & Brown & V P \\
\hline CNU87 & Moderately & S \& P & Gold & Purple \\
\hline CNU88 & Easy & S \& P & B F & V P \\
\hline CNU90 & Easy & S \& P & $\mathrm{B} \mathrm{F}$ & Purple \\
\hline CNU91 & Moderately & Absent & B F & Purple \\
\hline CNU93 & Easy & Absent & Straw & Purple \\
\hline CNU94 & Easy & S \& P & Straw & Purple \\
\hline
\end{tabular}

S \& P: Short and partly, S \& F: Short and fully, L \& F: Long and fully, B F: Brown furrows, B S: Brown spots on straw, L B: Light brown, V P: Variable purple

Table 6. Numbers of allelic band and PIC values of primers used in SSR analysis in 34 colored rice lines

\begin{tabular}{cccccc}
\hline Primer pair & $\begin{array}{c}\text { No. of allelic } \\
\text { band }\end{array}$ & $\begin{array}{c}\text { PIC } \\
\text { value }\end{array}$ & Primer pair & $\begin{array}{c}\text { No. of allelic } \\
\text { band }\end{array}$ & $\begin{array}{c}\text { PIC } \\
\text { value }\end{array}$ \\
\hline RM 503 & 3 & 0.48 & RM 579 & 5 & 0.67 \\
RM 504 & 2 & 0.60 & RM 457 & 2 & 0.08 \\
RM 528 & 3 & 0.52 & RM 553 & 3 & 0.48 \\
\cline { 4 - 5 } RM 577 & 2 & 0.52 & Overall mean & 3 & 0.48 \\
\hline
\end{tabular}

\section{Genetic diversity and grouping of 34 colored rice \\ varieties}

The presence of genetic diversity in crop populations is not easily detected by morphological characteristics of growing plants. The use of molecular markers is increasingly common method for the detection of differences at the DNA level in crop populations (Meng et al., 1998). The primary objective of this study was to assess genetic diversity between CNU lines using SSR markers.

Genetic distance between 34 colored rice lines ranged from 0.28 to 0.67 (Fig. 1). In the UPGMA clustering algorithm, all the 34 colored rice populations were classified into four groups and subdivided into several subgroups (Table 7); in the first group two subgroups were classified (Heukjinju and CNU33 as subgroup I-1,
Table 7. CNU lines classified into groups by SSR analysis

\begin{tabular}{lcl}
\hline $\begin{array}{l}\text { Large } \\
\text { group }\end{array}$ & Subgroup & \multicolumn{1}{c}{ Lines } \\
\hline I group & I-1 & Check (Heukjinju), CNU33 \\
& I-2 & CNU80, CNU83 \\
II group & II-1 & 4 lines including CNU40 \\
& II-2 & CNU46, CNU91 \\
II group & II-3 & 7 lines including CNU45 \\
IV group & - & CNU1, CNU32, CNU93 \\
& IV-1 & CNU2, CNU30, CNU44 \\
& IV-2 & CNU43, CNU 76 \\
& IV-3 & 5 lines including CNU48 \\
& IV-4 & CNU52, CNU77 \\
& IV-5 & CNU39 \\
\hline
\end{tabular}




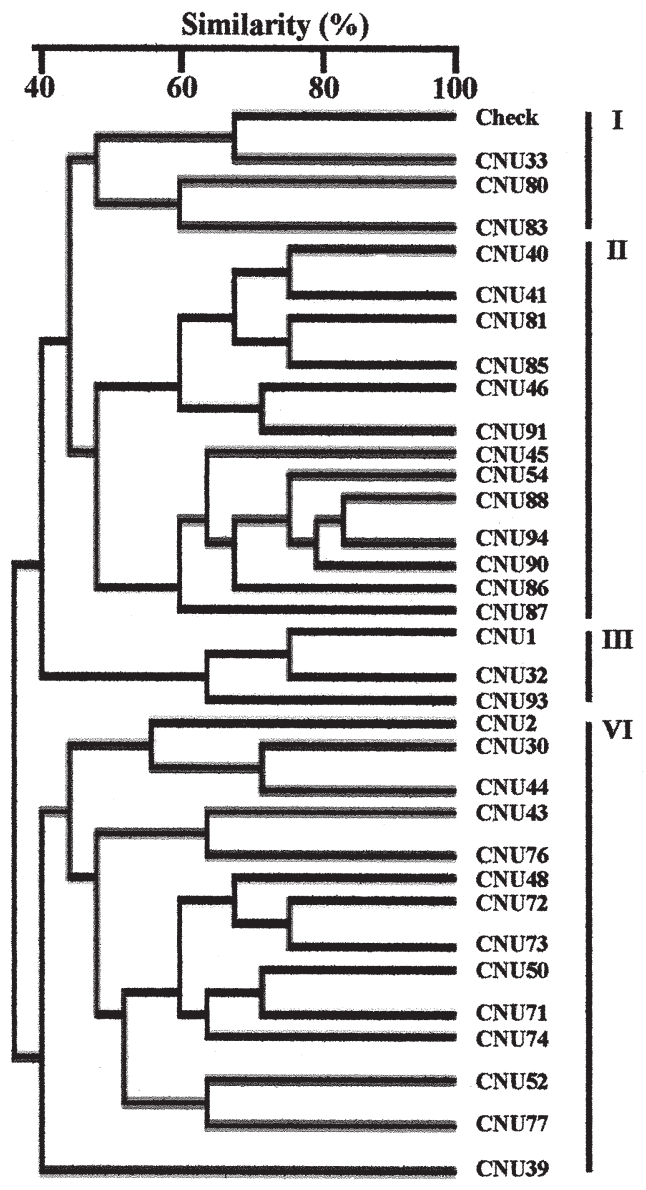

Fig. 1. Cluster analysis according to genetic distance calculated from SSR analysis in 34 colored rice lines.

CNU80 and CNU83 as subgroup I-2); in the second group three subgroups were classified (CNU40, CNU41, CNU81, CNU85, as subgroup II-1, CNU46, CNU91 as subgroup II-2, CNU45, CNU54, CNU88, CNU94, CNU90, CNU86, CNU87 as subgroup II-3); in the third group one subgroup was classified (CNU1, CNU32, CNU93); in the four group five subgroup were classified (CNU2, CNU30, CNU44 as subgroup IV-1, CNU43, CNU76 as subgroup IV-2, CNU48, CNU72, CNU73, CNU50, CNU71, CNU74 as subgroup IV-3, CNU52, CNU77 as subgroup IV-4, CNU39 as subgroup IV-5).

While in cluster analysis according to genetic distance calculated from agronomic characteristics, the 34 colored rice populations were classified into seven groups (Fig. 2); in the first group three subgroups were classified (Check, CNU30, CNU43, CNU74, CNU54, CNU81, CNU44, CNU88, CNU71, CNU90 as subgroup I-1, CNU86 as subgroup I-2, CNU1, CNU2, CNU72, CNU93, CNU94, CNU80 as subgroup I-3); in the second group two subgroups were classified (CNU46, CNU76, CNU87 as subgroup II-1, CNU50, CNU91 as subgroup II-2); in the third group one subgroup was classified (CNU77); in the fourth group one subgroup was classified (CNU41); in the fifth group two subgroups were classified (CNU39, CNU40, CNU83 as subgroup

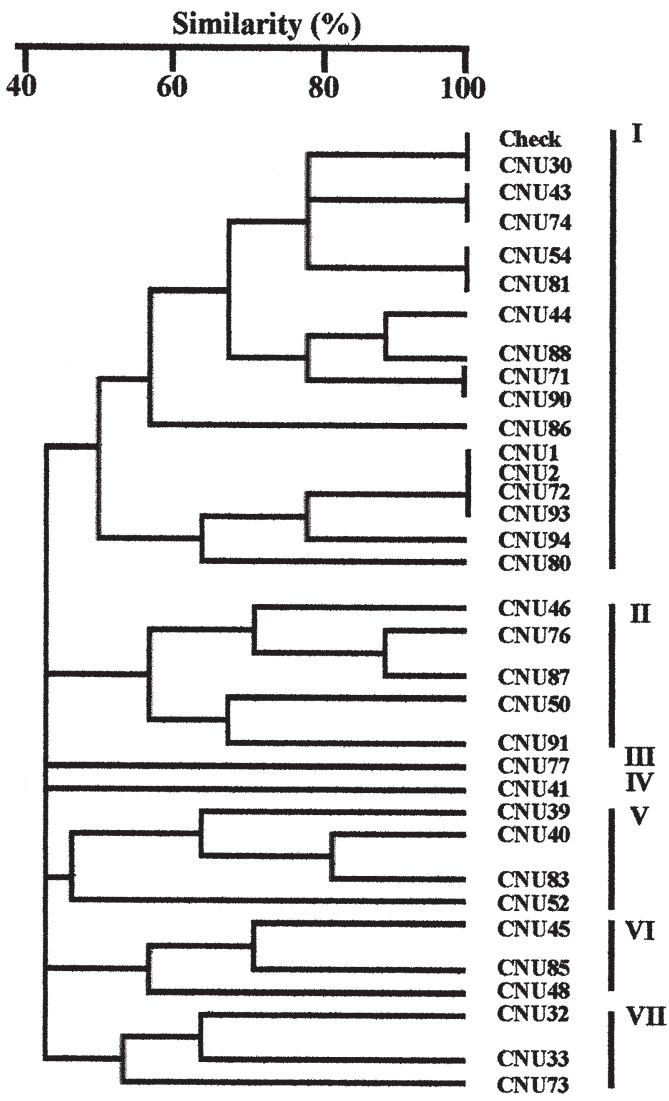

Fig. 2. Cluster analysis according to genetic distance calculated from agronomic characteristics in the 34 colored rice lines.

V-1, CNU52 as subgroup V-2); in the sixth group two subgroups were classified (CNU45, CNU85 as subgroup VI-1, CNU48 as subgroup VI-2); in the seventh group two subgroup were classified (CNU32, CNU33 as subgroup VII-1, CNU73 as subgroup VII-2).

\section{The genetic diversity of $34 \mathrm{CNU}$ lines and useful} lines

The evaluation of genetic diversity using SSR markers may be very useful not only for breeding programmer, but also for devising strategies for conserving and managing colored rice germplasm. The genetic distance in colored rice lines showed little different between agronomic characteristics and SSR analysis. In SSR analysis, they divided into 4 large groups (Fig. 1), but had 7 large groups according to genetic distance calculated from agronomic characteristics (Fig. 2). Relationships between colored rice will be a good indicator for breeders who are interested in developing new cultivars or improving colored rice populations. Information on genetic diversity within CNU lines may be useful in breeding program for line development and find linkage relationship. CNU71, CNU73, CNU83, CNU91 and CNU48 lines showed useful lines for high yields in 34 colored rice lines. 


\section{REFERENCES}

Brown-Guedira, G. L., J. A. Thompson, R. L. Nelson and M. L. Warburton 2000 Evaluation of genetic diversity of soybean introductions and North American ancestors using RAPD and SSR markers. Crop Sci., 40: 815-823

Chin, E. C. L., M. L. Senior, H. Shu and J. S. C. Smith 1996 Maize simple repetitive DNA sequences: abundance and allele variation. Genome, 39: 866-873

Dubreuil, P., P. Dufour, E. Krejcl, M. Causse, D. De Vienne, A. Gallais and A. Charcosset 1996 Organization of RFLP diversity among inbred lines of maize representing the most significant heterotic groups. Crop Sci., 36: 790-799

Elliott, W. A. and G. J. Perlinger 1977 Inheritance of shattering in wild rice. Crop Sci., 17: 851-853

Gauthier, P., B. Gouesnard, J. Dallard, R. Redaelli, C. Rebourg, A. Charcosset and A. Boyat 2002 RFLP diversity and relationships among traditional European maize populations. Theor. Appl. Genet., 105: 91-99

Ghebru, B., R. J. Schmidt and J. L. Bennetzen 2002 Genetic diversity of Eritreansorghum landraces assessed with simple sequence repeat (SSR) markers. Theor. Appl. Genet., 105: 229-236

Hedrick, P. W. 1985 Genetics of populations. Jones and Bartlett Publ. Inx, Boston, Massachusetts

Hospital, F, L. Moreau, F. Lacoudre, A. Charcosset and A. Gallais 1997 More on the efficiency of marker-assisted selection. Theor. Appl. Genet., 95: 1181-1189

Kumar, L. S. 1999 DNA markers in plant improvement: an overview. Biotechnol. Adv., 17: 143-182

Meng, E. C. H., M. Smale and D. Grimanelli 1998 Definition and measurement of crop diversity for economic analysis. IPGRI publication, Rome, pp. 19-29

Mohan, M, S. Nair, A. Bhagwat, T. G. Krishma, M. Yano, C. G. Bhatia and T. Sasaki 1997 Genome mapping, molecular markers and marker-assisted selection in crop plants. Mol. Breed., 3: 87-103

Moon, H. P., Y. G. Choi, J. H. Lee, K. H. Jung, S. Y. Cho, H. G. Hwang, K. H. Kang, M. K. Kim, K. H. Hwang, H. C. Choi and Y.
S. Kim 1998 A new early maturing, anthocyanin pigmented rice variety "Heugjinjubyeo". RDA J. Crop Sci. II, 40: 67-74.

Nei, M. and W. H. Li 1979 Mathematical model for studying genetic variation in terms of restriction endonucleases. Proc. Natl. Acad. Sci. USA, 76: 5269-5273

Porter, R. A., A. W. Grombancher, B. J. MacGregor and H. J. Schumer 1994 Wild rice breeding. In "Minnesota Wild Rice Research 1993", Univ. Minn, St. Paul, Minnesota, pp. 41-54

Rafalski, J. A., J. M. Vogel, M. Morhante, C. Andre and S. V. Tingey 1996 Generating and using DNA markers in plants. In "Non-mammalian genomic analysis: a practical guide", ed by B. Birren and E. Lai, Academic Press Inc., San Diego, pp. $75-135$

Saal, B. and G. Wricke 1999 Development of simple sequence repeats in rye. Genome, 42: 964-972

Schertz, C. E. and I. J. Boedicker 1977 Harvest losses and study of separation within the combine. In "Progress Report of 1976 wild rice research", Univ. Minn, St. Minnesota, pp. 91-96

Singh, A., M. S. Negi, J. Rajagopal, S. Bhatia, U. K. Tomas, P. S. Srivastava and M. Lakshmikumaran 1999 Assessment of genetic diversity in Azadirachta indica using AFLP markers. Theor. Appl. Genet., 99: 272-279

Staub, J. E., F. C. Serquwn and M. Gupta 1996 Genetic markers, map construction, and their application in plant breeding. Hortscience, 31: 729-741

Van de Peer, Y. and R. De Wachter 1994 TREECON for windows: a software package for the construction and drawing of evolutionary trees for the construction and drawing of evolutionary trees for the Microsoft Windows environment. Compu. Applic. Biosci., 10: 569-570

Woods, D. L. and K. W. Clark 1976 Preliminary observations on the inheritance of non-shattering habits in wild rice. Can. J. Plant Sci., 56: 197-198

Yu, K. and K. P. Pauls 1994 Optimisation of DNA-extraction and PCR procedures for random amplified polymorphic DNA (RAPD) analysis in plants. In "PCR Technology: Current Innovations", ed by H. G. Griffin and A. M. Griffin, pp. 193-200, CRC Press, Boca Raton, FL. 